CIRJE-F-814

\title{
The Effectiveness of Non-traditional Monetary Policy Measures: The Case of the Bank of Japan
}

\author{
Kazuo Ueda \\ University of Tokyo
}

August 2011; Revised in October 2011

CIRJE Discussion Papers can be downloaded without charge from:

http://www.cirje.e.u-tokyo.ac.jp/research/03research02dp.html

Discussion Papers are a series of manuscripts in their draft form. They are not intended for circulation or distribution except as indicated by the author. For that reason Discussion Papers may not be reproduced or distributed without the written consent of the author. 
October 2011

\title{
The Effectiveness of Non-traditional Monetary Policy \\ Measures: The Case of the Bank of Japan*
}

\author{
Kazuo Ueda \\ Faculty of Economics \\ The University of Tokyo
}

\begin{abstract}
This paper summarizes non-traditional monetary policy measures adopted by the Bank of Japan (BOJ) during the last two decades and by other G7 central banks since the start of the current global financial turmoil and analyzes the effectiveness of such measures. The paper begins with a typology of policies usable near the zero lower bound on interest rates (ZLB). They are:(i) forward guidance of future policy rates;(ii) targeted asset purchases;(iii) and quantitative easing (QE). Using this typology, I review the measures adopted by the BOJ and other central banks. I then offer a news analysis of the effects of the measures adopted by the BOJ on asset prices, comparing them with those adopted by the Fed. Many of the measures, with the exception of strategy (iii), are shown to have moved asset prices in the expected directions. Another exception is that most of the monetary easing measures failed to weaken the yen. Despite some effects on asset prices, however, the measures have failed to stop the deflationary trend of the Japanese economy clearly. I discuss some possible reasons for this and more general implications for monetary policy.
\end{abstract}

JEL Classification Numbers: E43, E52, E58, G12.

Address of the author: Department of Economics, The University of Tokyo, 7-3-1 Hongo, Bunkyo-ku, Tokyo 113-0033 Japan. E-mail: ueda@e.u-tokyo.ac.jp, fax:81-3-5841-5521.

*based on the presidential address given at the Japanese Economic Association Meeting at Kumamoto Gakuen University, May 22, 2011. I would like to thank an anonymous referee for many helpful comments on an earlier version. 
This paper attempts to add to the growing literature on the effectiveness of the so-called non-conventional monetary policy measures on asset prices and the economy. The major contribution of the paper is first the classification of the policy measures adopted by major central banks into three types, forward guidance of policy rates, large scale asset purchases and quantitative easing. Second, the paper offers an event study analysis of the BOJ's policy measures by comparing it with that of the Fed. Third, the paper discusses some possible reasons for the failure, notably in Japan but also in many other countries, of non-conventional measures to lift the economy and inflation within short periods of time.

The rate of change in the ex energy-food component of Japan' Consumer Price Index (henceforth, CPI) fell below zero in early 1999 and has been negative since then with only minor exceptions. During this period the BOJ has used many so-called non-traditional monetary policy measures in an attempt to stop the deflation. The attempt, however, has so far not succeeded clearly. This episode is interesting in itself, but also in light of the current disinflationary tendencies of the developed economies and central banks' attempts, especially by the Fed, to stop them. Many of the measures central banks are currently using are those that were used by the BOJ earlier. Thus, the experience of the BOJ seems to warrant a careful review.

In section $1 \mathrm{I}$ begin with a typology of policies usable at low inflation and interest rates. In section 2 I explain the measures adopted by the BOJ and other G7 central banks, using this typology. Section 3 is devoted to the discussion of evidence on the effectiveness of the measures. I also offer new evidence based on news and regression analyses. In section $4 \mathrm{I}$ discuss the relationship between the statistical findings and monetary policy measures adopted by G7 central banks during 2007-2010. In addition, I discuss possible reasons for the failure of the BOJ to stop deflation.

\section{1, Typology of Policy Options near the ZLB}

There is now a fairly widely accepted classification of policies usable near the ZLB. ${ }^{1}$ That is, they can be classified into: (i) forward guidance of expectations of future short rates - providing assurance to the market that policy rates will be lower in the future than currently expected ${ }^{2}$; (ii) changing the composition of the central bank's balance sheet so as to increase the central bank's holdings of non-traditional assets (targeted asset purchases); and (iii) expanding the size of the central bank's balance

\footnotetext{
1 See, for example, Bernanke \& Reinhart (2004).

${ }^{2}$ See, for example, Clarida (2010)
} 
sheet beyond the level required for a zero policy rate $(\mathrm{QE})$. This is summarized in Table 1.

In order to clearly differentiate between (ii) and (iii), it would be useful to think of (iii) as an attempt to expand the balance sheet by purchases of traditional assets, say, treasury bills. Then, an expansion of a central bank balance sheet based on purchases of non-traditional assets is a combination of (ii) and (iii). Strong forms of quantitative easing are accompanied by a target on the size of central bank balance sheet or its component.

Many central banks, in their recent pursuit of strategy (ii) since 2007, have not tried to mop up the excess liquidity created. That is, they left the funds supplied unsterilized, giving the appearance that they have been pursuing $\mathrm{QE}$. This gives rise to an alternative typology with respect to strategies (ii) and (iii). Strategy (iii) may be regarded as pure QE--QE0, while unsterilized versions of strategy (ii) have consisted of two types: one, purchases of assets in distressed markets, QE1, and, the other, asset purchases in more normal markets, QE2. ${ }^{3}$ Another name for QE1 has been credit easing and is aimed at containment of liquidity/risk premiums in markets under stress. Asset purchases under QE2 have had the intention of generating portfolio rebalancing effects. ${ }^{4}$ This typology is also summarized in Table 1.

The theoretical rationale behind these approaches has now become fairly clear. The rationale for policy (i) has been clearly stated by Woodford (1999). He argued that "it is unlikely that monetary policy can do much to loosen the constraint imposed by the zero bound, except by changing what people expect policy to be like after the constraint ceases to bind." In other words, central banks can affect today's medium- to long-term interest rates by promising a longer period of a zero rate than is currently assumed by the market. I may also note that the first proponent of this policy was Krugman (1998) who stated the case in terms of the framework of quantitative easing and hence made it somewhat difficult for policymakers to understand what essentially was involved.

The rationale for QE1 type measures seems clear. In the terminology of Allen and Gale (2007), during financial crises "cash in the market" pricing of assets prevails and asset prices diverge from fundamentals. It would be a good idea for central banks to improve market liquidity by purchasing such assets. ${ }^{5}$ Alternatively, central banks can

\footnotetext{
${ }^{3}$ The market has used the term QE2 to mean a second round attempt at quantitative easing, which is different from, although not quite inconsistent with, the usage of the term here.

${ }^{4}$ Some of the credit easing measures that have been employed involved no purchases of assets. For example, the central bank can lend to financial institutions against distressed assets in which case this may appear just like a normal operation as far as the central bank balance sheet is concerned.

${ }^{5}$ Curdia and Woodford (2010) show that when financial market imperfections are important, targeted asset purchases or credit easing, can be effective. One example they cite is the following.
} 
buy such assets with agreement to resell them at later dates or lend against them.

The rationale for QE2 is less clear cut. Simply put, this strategy aims at changing asset prices by changing relative asset supplies in the market, in turn affecting aggregate demand for goods and services. Whether such effects exist or not is an old question in monetary economics. Doh (2010) explains that such effects are present in the market for government bonds if investors at different maturities are separated. ${ }^{6}$ Viewed in this way, QE2 assumes the existence of market imperfections for its effectiveness as does QE1. In this sense QE1 and QE2 may not be clearly separable. For convenience, however, I maintain the distinction that QE1 assumes malfunctioning of markets, while QE2, more long-lasting imperfections such as differences in investor habitats.

Whether QE0 affects asset prices and or the economy seems to be an unsettled question. Bernanke and Reinhart (2004) discuss three possible channels: (a) the portfolio rebalancing effect, whereby increases in the monetary base would lead the private sector to rebalance its portfolios by lowering yields on alternative, non-monetary assets; (b) altering expectations of the future path of policy rates by a visible act of setting and meeting a high reserve target; and (c) the expansionary fiscal effect, whereby the central bank replaces public holdings of interest-bearing government debt with non-interest-bearing currency or reserves, thus replacing the expected future tax liability for the public with an inflation tax. For channel (c) to produce meaningful effects, the growth rate of base money, however, has to be unusually high. Also, the liquidity supplied will have to be in the economy permanently. Otherwise, there will be a period of negative seigniorage growth. Theoretical rationale behind channel (a) is not obvious because in the case of QE0, unlike in the case of QE2, base money is supplied in exchange for treasury bills with a zero rate; the transaction is an exchange of two very close substitutes. Thus, at this point, the theoretical case for QE0 seems fairly weak. $^{7}$

\section{2, Unconventional Monetary Policy Measures Adopted by G7 Central Banks}

\section{The BOJ: 1998-2011}

The burst of the land and stock price bubbles in the early 1990s threw the

Only specialists have the expertise to trade commercial paper, but developments adversely affect the capital of these specialists, resulting in a deviation of commercial paper yields from fundamentals. And, they support central bank purchases of commercial paper in such a case. This seems to be an alternative justification for QE1. It may be used to justify QE2 in certain cases, but the justification seems to become a little bit stretched.

${ }^{6}$ This is, of course, the Modigliani and Sutch (1966) argument.

${ }^{7}$ Curdia and Woodford (2010) show that in their model QE0 has no effect on the economy. 
Japanese economy into a serious stagnation that turned on negative accelerator effects generated by declining asset prices. The BOJ reduced the overnight interest rate to below $0.5 \%$ already in the summer of 1995, from the high of $8.6 \%$ in 1991 . Despite this, the economy experienced a severe credit crunch in 1997-1998. The overnight rate was lowered to virtually zero by early 1999 . The inflation rate became negative in the second half of 1998 and has not been in the positive territory for an extended period since then. Thus, the economy has been effectively in a "liquidity trap" for 15 years.

The BOJ continued its exploration for further easing measures in 1999 and the 2000s. I summarize in Table 2 the BOJ's policy measures during 1999-2011 in terms of the typology offered in Table 1 . The policy measures are ordered chronologically and the table also shows what strategies they tried to employ. ${ }^{8}$

The so-called zero interest rate policy (ZIRP) - the core of the BOJ's monetary policy since 1999--was introduced in April 1999. The ZIRP was not just a zero short-term interest rate, but a commitment to maintain it "until deflationary concerns were dispelled", and thus was a major example of forward guidance strategy. ${ }^{9}$

In August 2000, the BOJ lifted the ZIRP and raised the overnight call market rate to $0.25 \%$. The world economy, however, fell into a serious recession as the IT bubble collapsed in 2001, with negative effects on Japan's financial system and the economy. In response, the BOJ adopted the quantitative easing policy--let us call it QEJ, Japan's version of QE--in March 2001. QEJ consisted of three pillars. First, the BOJ maintained an ample liquidity supply by using the CABs at the BOJ, essentially bank reserves, as the operating policy target. Second, the BOJ committed itself to maintaining the provision of ample liquidity until the rate of change of the CPI became zero percent or higher on a sustained basis. Third, the BOJ increased the amount of purchases of Japanese Government Bonds (JGBs) from time to time as a tool for liquidity injection. It was projected that increasing the $\mathrm{CAB}$ target beyond the level of the required reserves would normally keep the call rate near zero percent. Thus, with the commitment to maintain ample liquidity provision until deflation ended, QEJ contained a version of the ZIRP, or strategy (i).

The target on the CABs was increased from approximately 5 trillion yen at the introduction of QEJ in March 2001, an amount roughly 1 trillion yen greater than the

\footnotetext{
${ }^{8}$ The list appearing in the table is not exhaustive. It does not include, for example, the increase in the current account balances (CAB) target announced in March 2003, which was done to merely accommodate an increase in the demand for CABs due to the start of transaction between Japan Post and the BOJ.

${ }^{9}$ Some use the ZIRP to mean only a zero policy rate. Here it refers to the combination of a zero rate and the commitment to maintain it until deflation ends.
} 
then-required reserves, to a range of approximately 30-35 trillion yen in January 2004 . The increases in the CABs were achieved mainly by market operations, including the BOJ's purchases of JGBs. The amount of JGB purchases was 0.4 trillion yen per month in March 2001 and was gradually increased to 1.2 trillion yen by May 2004. QEJ was finally lifted in March 2006. The extent of the BOJ's balance sheet expansion was unprecedented at that time and is comparable to that of other central banks during the late 2000s.

In Table 2 the introduction of QEJ in March 2001 is indicated to have involved all three strategies. QEJ contained purchases of JGBs and the BOJ explained that the purchases were an attempt to hit the target on the CABs and not to generate portfolio rebalancing effects. I classify, however, such JGB purchases as a QE2 type measure because it does not seem appropriate to deny a priori such portfolio rebalancing effects. Some of the moves after March 2001 involved QE2 in this sense, while some others did not. For example, on April $30^{\text {th }} 2003$ the BOJ increased only the target on the CABs; hence, the move is classified as QE0.

The BOJ had exited from QEJ in 2006, but has had to resort again to non-conventional measures in response to spillovers to Japan's financial system and the economy of the world financial and economic crisis during 2007-09. Measures employed since 2008 have not involved QE0. Most of them have been either QE1 or QE2. One of the first was the establishment of the yen/dollar swap scheme between the BOJ and the Fed and accompanying dollar supplying operations by the BOJ. This move was designed to ease the dollar shortage problem among non U.S. financial institutions during the height of the international financial crisis of 2007-09 and its spillover to the domestic money market. It was clearly a QE1 type action.

In many cases, however, the distinction between QE1 and QE2 is not as clear cut. For example, on December 19, 2008 the BOJ decided to increase purchases of JGBs, but also to include inflation indexed bonds, floating rate bonds and 30 year bonds in the list of JGBs the BOJ bought. It is well known that the market for inflation indexed JGBs was dysfunctional after the Lehman shock so that the decision to purchase these bonds may be classified as QE1, while other JGB purchases may be more appropriately classified as QE2. Similarly, at the time of the decision to purchase commercial papers (CPs) in December 2008 the market was very likely under severe stress; thus, the decision to purchase them is classified as QE1. In contrast, Comprehensive Monetary Easing (CME) introduced in October 2010 included the decision to expand the purchases of CPs which may be classified as a QE2 type action, given the recovery in the functioning of the market. 
The table also shows that there has been occasional use or strengthening of Strategy (i) during the last 12 years in addition to the introduction of ZIRP in April 1999. For example, in October 2003 the condition for exit from QE was clarified. Previously, it was when CPI inflation became positive. It was then changed to when the trend movement of CPI inflation became positive and a return to negative inflation rate was unlikely in the foreseeable future. In December 2009, the BOJ clarified its understanding of price stability. At that time some observers thought that the BOJ was trying to target the lower end of the understanding of price stability, which was zero to two percent. In the December $19^{\text {th }}$ meeting the BOJ announced that the midpoint of the range, one percent, was the most preferred inflation rate.

In addition, throughout the period, the BOJ relied on strategy (ii), mostly QE1, extensively to contain the rise in liquidity and risk premiums in the financial system. In the spring of 2003 the BOJ decided to purchase Asset Backed CPs (ABCPs) and ABSs outright. Separately, the BOJ had established a standby scheme that allowed banks to sell equities they held to the BOJ in 2002. Banks could certainly sell stocks in the market. Given the then low liquidity of the market, however, banks may have been reluctant to sell stocks and lower prices themselves.

\section{Non-traditional Policies adopted by other G7 central Banks since 2007}

A rough summary of non-traditional policies adopted by other G7 central banks is provided in Table 3. As can be seen, strategy (ii) has been used by most central banks, while the other strategies have been only sparingly employed. This has also been the case with the BOJ as summarized above.

\section{Strategy (i)}

Very few central banks have used a strong explicit version of expectations management. One exception has been the Bank of Canada who issued a statement on April 21, 2009 that "conditional on the outlook for inflation, the target overnight rate can be expected to remain at its current level until the end of the second quarter of 2010 in order to achieve the inflation target." The Fed has used a much weaker form of a similar statement since December 16, 2008 when it said that "the committee anticipates that weak economic conditions are likely to warrant exceptionally low levels of the federal funds rate for some time." 10 Riksbank has published an expected path of the

10 In August 2011 the Fed strengthened the statement to mean that a near zero federal funds rate was expected to stay until the middle of 2013 . However, the relationship 
policy rate. None of these, however, are as explicit as the BOJ's commitment during 1999-2006 regarding the relationship between inflation and the durability of low interest rates. $^{11}$

\section{Strategy (ii)}

Strategy (ii) has been the major toolkit for many central banks during the current crisis. Many central banks have started or enlarged programs to purchase non-traditional assets. In the area of private credit, the BOE has bought CPs and corporate bonds; the ECB, covered bonds; and the Fed, agency bonds and agency MBSs.

Most central banks have both lengthened the terms of and expanded the menu of eligible collateral for liquidity supplying operations. For example, the fixed rate full-allotment liquidity program of the ECB has been offered at subsidized rates relative to the market and met with huge subscriptions. In addition, some have taken non-standard assets as collateral. For example, the Fed has lent against ABSs under the TALF program and against CPs and ABCPs under AMLF, CPFF and MMIFF programs. Many central banks have also lent to non-standard entities. For example, the Fed has lent to nonbanks such as broker-dealers, money market mutual funds and investors in ABSs. Another significant move has been the supply of US dollars in non-US markets under the dollar swap program between the Fed and other central banks.

The characterization of all these moves as nontraditional may be problematic. Some may be more appropriately regarded as an expansion of usual liquidity provision. ${ }^{12}$ Also, the definition of nontraditional assets and/or entities differs from country to country. Thus, no attempt is made here to offer a more rigorous definition/characterization of strategy (ii) or credit easing in the current episode.

between the duration of a zero rate and macroeconomic conditions is still unclear. Also, it is speculated that the Fed resorted to this measure because of the difficulty to restart QE. As a result, one still obtains the impression that the Fed is viewing this as a supplementary measure.

${ }_{11}$ The measures adopted by the ECB, the fixed rate, full allotment of term funds seem to have had similar effects on money market term rates to those that arise when central banks use strategy (i) and promise to keep the policy rate at low levels for, say, three or twelve months. The two types of measures, however, are not equivalent. For example, under the ECB type term fund supplying scheme, central banks can terminate the program and raise policy rates at any point, while under strategy (i) they will have to hold policy rates at low rates for the duration of the promise. A similar measure was adopted by the BOJ in December 2009 and expanded later. See Table 2.

12 Bernanke (2009) and Madigan (2009) attempt to characterize some of these operations as an expansion of the traditional lender of last resort function of central banks. There are, however, differences between LLR and credit easing. Under LLR central banks are easing problems on the liability side of, while under many of the credit easing measures central banks are easing problems related to specific assets held by private banks 
One remaining issue regarding strategy (ii) is the characterization of purchases of government bonds. Most major central banks have either started or expanded the program to purchase government bonds. ${ }^{13}$ The BOE has characterized it as an element of quantitative easing, i.e., strategy (iii), still leaving the question whether it is QE0 in strategy (iii) or QE2 in strategy (ii). In contrast, the Fed stated in its 2009 March FOMC statement that "to help improve conditions in private credit markets, the Committee decided to purchase up to $\$ 300$ billion of longer-term Treasury securities." Thus, government bond purchases are regarded as an element of credit easing by the Fed, probably a QE2 type action. ${ }^{14}$ The BOJ considered the purchases as simply a means of liquidity provision at low frequency, but with the introduction of the CME framework in October 2010, it stated explicitly that purchases of JGBs under the framework are an attempt to lower interest rates, i.e., a QE2 type action. It is probably difficult to justify government bond purchases as a central bank response to sharp declines in market liquidity. ${ }^{15}$ It seems fair to say that central banks have not found a uniform answer to the question of why they buy government bonds.

\section{Strategy (iii)}

During the current crisis no central banks have used a strong version of this strategy. One that comes close to is the BOE who has set an upper limit for its purchases of government bonds and stated that the bond purchases would have the effect of increasing the money supply, which in turn would stimulate the economy. The BOE has called this scheme quantitative easing. Even in this case, no policy target has been set for a measure of the quantity of money unlike the case of the BOJ during 2001-06.

On the other hand, most central banks have expanded their balance sheets and, as a result, excess reserves have been well above zero; that is, they adopted weak forms of quantitative easing. Such an expansion of central bank balance sheets seems to have been a result of strategy (ii) rather than of an explicit attempt to employ strategy (iii), i.e., either QE1 or QE2 rather than QE0. Use of targeted asset purchases, say, requires an injection of reserves to the system. In order to avoid an expansion of its balance sheet the central bank needs to drain the system of the same amount of reserves. It appears that many central banks have decided not to carry out such un-sterilization. Some seem

\footnotetext{
13 The ECB started to buy member country government bonds in 2010, but largely as a response to the debt crisis of Greece and other countries rather than as a monetary policy action.

${ }_{15}$ See Footnote 3 for the sense QE2 is used here.

15 An exception is the market for Japan's inflation indexed bonds and variable rate bonds as I stated in the previous section.
} 
to have thought that the existence of positive amounts of excess reserves would act as a liquidity buffer in the case of a worsening of counterparty risk perception; some others lacked the tool for mopping up the excess reserves promptly.

The meaning of the expansion of central bank balance sheet has become even more blurred due to the increased practice of paying interest on bank reserves. The Fed and BOJ have recently started this practice as a means of maintaining the policy rate at positive levels when excess reserves are positive as a result of, say, credit easing policies as explained above. Payment of interest on excess reserves certainly lowers private banks' incentive to turn the reserves to other interest earning assets and thus undermines the stimulative power of "quantitative easing." 16 It is, on the other hand, an effective tool to raise market interest rates even in the presence of significant excess reserves.

The choice of monetary policy strategies adopted by G7 central banks since 2007 seems to have been importantly affected by the experience of the BOJ during 1998-2006. Thus, let us now turn to discussion of the effectiveness of the policies adopted.

\section{3, Evidence on the Effectiveness of the BOJ's Monetary Policy}

Summarizing the literature on the effectiveness of the BOJ's non-traditional monetary policy carried out during 1998-2006, Ugai (2007) states that his survey "confirms a clear effect whereby the commitment to maintain the Quantitative Easing Policy fostered the expectations that the zero interest rate would continue into the future, thereby lowering the yield curve centering on the short- to medium-term range," and that "there were also phases in which an increase in the current account balances held by financial institutions at the BOJ bolstered this expectation. While the results were mixed as to whether expansion of the monetary base and altering the composition of the BOJ's balance sheet led to portfolio rebalancing, generally this effect, if any, was smaller than that stemming from the commitment." Thus, according to him, strategy (i), forward guidance, was effective, but QE0 was not quite except for its effect of enhancing the commitment contained in strategy (i). It is unclear whether QE1 or QE2 generated expected effects. Apart from Ugai's summary, there seems to be some evidence that QE1 was effective.

Examples of existing analyses of the BOJ monetary policy during the period are as

\footnotetext{
${ }^{16}$ Curdia and Woodford (2009) show that under certain assumptions it is optimal to satiate the system with excess reserves and pay an interest rate on reserves equal to the policy rate.
} 
follows. Concerning strategy (i), both Okina \& Shiratsuka (2004) and Oda \& Ueda (2007) show that the BOJ's commitment to maintain a zero rate until deflation ended produced strong effects on expected future short rates, thus on current medium- to long-term interest rates.

Baba et al. (2006) tries to disentangle among the effects of various components of QEJ on interest rates. Using a panel data set on bank negotiable certificate of deposit rates, it shows that, after controlling for the effects of changes in bank creditworthiness, the dummies for the ZIRP and QEJ periods exerted significant negative effects on the rates, while the QE0 aspect of QEJ, that is, the amount of the CABs at the BOJ did not lower the rates. The significance of the ZIRP and QEJ dummies may be thought to indicate the effectiveness of the strategy (i) aspect of the two frameworks. The paper also shows that, for the QEJ period, the average maturity of the BOJ's fund supplying operations exerted significant effect on the rates. The BOJ had found it increasingly difficult, and thus resorted to longer and longer fund supplying operations to hit the target on the CABs during this period. To the extent that the money market was still dysfunctional, these operations may be regarded as of the QE1 type, while to the extent that it was back to normal, they were of type QE2. The paper and other studies also point to the effectiveness of QE1 type operations such as $\mathrm{CP}$ purchases for containing risk premiums. ${ }^{17}$

In contrast to this, researchers have not found significant effects of the BOJ's purchases of JGBs, a QE2 type measure, on their yields. Thus, Oda \& Ueda (2007) fail to find any significant effects of the BOJ's purchases of JGBs on either the expected future short rates or risk premiums on JGBs. ${ }^{18}$ The failure may be due to the technical difficulty of separating the effects of JGB purchases from those of the commitment to maintain a zero rate. Alternatively, it could be a result of the fairly short remaining maturity of the JGBs purchased by the BOJ. ${ }^{19}$

In this paper I add some new light on the evidence of the effectiveness of the BOJ's non-conventional monetary policy measures based on the news analysis. Such an analysis is motivated by recent analyses of the Fed's non-conventional monetary policy measures. A significant portion of these analyses have based their conclusions on the results of the news analysis. ${ }^{20}$ Thus, it would be interesting to see what would happen

\footnotetext{
${ }^{17}$ See, for example, the BOJ (2009).

${ }^{18}$ One exception is Bernanke, Reinhart and Sack (2004), who carry out a macro finance analysis of the ZIRP and QEJ. They find statistically significant links between the BOJ's purchases of JGBs and JGB yields.

${ }_{19}$ The remaining maturity of JGBs bought by the BOJ declined to less than 4 years in 2005 . See McCauley and Ueda (2009).

${ }^{20}$ Examples are D’Amico \& King (2010), Gagnon, Raskin, Remache \& Sack (2010),
} 
if the same method of analysis was applied to the Japanese experience. The following analysis also covers the post QEJ period.

It is important to recognize the short-comings of the news approach. In a news analysis, important news events or dates that may affect asset prices are first identified. Then, asset prices right after the news are examined to see if they moved in expected directions. As such, the news analysis does not make clear, for example, if changes in asset prices on the day of a policy announcement may have been a result of other non-identified factors rather than monetary policy. Also, policy measures may require more than just a day or two to move asset prices if their interpretation was not straightforward. No statistical inferences are possible without the help of other tools. The approach is not suited for analyzing the effects of monetary policy on real variables of the economy. Confirmation of the effects of policy measures on asset prices lasting a day or two may not mean much for the question of whether the measures are useful for stopping deflationary forces in the economy.

Nonetheless, the news analysis is a convenient way of summarizing the response of asset prices to monetary policy changes. In the following, I will report on the results of a news analysis of Japanese monetary policy, focusing on measures adopted since 1999..$^{21}$

In Table 4, I reproduce the news analysis results of Yellen (2011) for the U.S. I may note that the November 2008 and March 2009 announcements to buy MBS and agency debt can be classified as QE1. The March 2009 and November 2010 decisions to buy U.S. Treasuries were more of QE2 type actions. ${ }^{22}$ The Table shows that interest rates declined across the board fairly substantially on key monetary policy announcement dates. Taken at face value, the November 2008 announcement to purchase MBS and Agency debt, QE1, led to declines in not just MBS rates but also to those of Treasuries and corporate bonds. Thus, operations in one dysfunctional market seem to have led to the containment of disruptions in other markets or have generated portfolio rebalancing effects. $^{23}$

Krishnamurthy \& Vissing-Jorgensen (2011) and Yellen (2011).

${ }^{21}$ Lam (2011) has recently conducted an even study analysis of the BOJ's policy measures and obtained results similar to those in the current paper. Lam, however, focuses mainly on the effects of CME on asset prices, while the current paper studies the effectiveness of a broader set of measures.

${ }^{22}$ I emphasize again that the use of the terminology QE1 and QE2 is different from the way they are used by market commentators of monetary policy.

${ }_{23}$ There are also regression analyses of the effects of the Fed's purchases of Treasuries on their yields. See, for example, Gagnon, Raskin, Remache \& Sack (2010). Typically, treasury yields are regressed on the share of treasury bonds held by the private sector along with other variables. This literature has found that the effects are statistically significant. It appears, however, that the result 
In Table 5 I present the response of asset prices to the BOJ's monetary policy measures summarized in Table 2. Asset prices chosen are Nikkei 225, the yen/dollar rate, JGB yields at 2, 5, 10, 30 year maturities, 1 year swap rate, and single A rated corporate bond rate. The data are taken from Bloomberg. Entries are in most cases asset price changes during the two days after the announcement of a policy measure, that is, the day of the policy change and the day after that. The two day window was chosen because in some cases policy changes were not announced before the close of the market. Also, asset prices sometimes reacted to comments of the BOJ governor during press conferences which were held after the close of the market. In addition, the markets seem to have responded only slowly to the introduction of a truly new policy measure, most notably, the ZIRP in April 1999. Thus, asset price responses during one week and one month windows, in addition to the two day window, are shown in the table with respect to this measure. Similarly, the table also shows asset price changes during one week following the introduction of QE in March 2001.

The cells shaded are those where asset prices moved in the expected direction. A glance at the table reveals that asset prices moved in the expected directions in most cases with two notable exceptions. The first exception is the yen dollar rate. Although some measures did lead to a weaker yen, most moved the yen in the opposite direction, i.e., they led to a stronger yen. ${ }^{24}$ The BOJ's monetary policy measures do not seem to have been major news to the foreign exchange market.

The second notable exception to the response of asset price changes to monetary policy is those to QE0 type measures. The response of interest rates and the exchange rate to increases in the $\mathrm{CAB}$ target are weak or in wrong directions. This is in contrast to the response of interest rates in the expected direction to $\mathrm{CAB}$ target changes when they are accompanied by changes in the amount of JGB purchases. This result is consistent with the theoretical prediction that QE0 by itself does not exert significant effects on asset prices or the economy. Another important implication of these two findings is that the claim that foreign exchange market intervention is more powerful when it is un-sterilized is groundless at the ZLB. Un-sterilized intervention at the ZLB is intervention plus QE0 and, hence, is equal in its impact to intervention if QE0 is ineffective.

depends on the inclusion of the period of the Treasuries buyback of 30 year bonds.

${ }^{24}$ It is to be noted that the monetary easing at the end of 2008 that involved an interest rate cut and the introduction of fixed rate term fund supplying operations in late 2009 and its expansion in 2010 did lead to weaker yen. The latter was also accompanied by strengthening of the time duration effect, strategy 1 . These two were major monetary easing among the many measures adopted during the period. It is still a puzzle that the introduction of QE in March 2001 or CMP in October 2010 did not lead to a weaker yen. 
Apart from these exceptions, the monetary easing measures lowered interest rates and raised stock prices. In contrast to the perverse response of the exchange rate, stock prices responded fairly significantly to most of the easing measures. In addition, JGB yields declined in response to most of the easing measures with the exception of QE0 type measures as discussed. This result is at odds with the consensus view in the literature that JGB purchases exerted no discernible effects on JGB yields.

In Table 6 the effects of more specifically targeted asset purchases are shown. These include purchases of equities, ABSs and inflation indexed JGBs. As can be seen, the effect of the measures is clearest in the case of inflation indexed bonds. Yields on indexed bonds declined sharply in response to the announcement of, or increases in the amount of purchases of, indexed bonds by the BOJ. Equity purchases raised equity prices in two of the three cases, while the ABS purchases did not affect the yield of the closest asset, corporate bonds.

While such news analysis is useful for summarizing the immediate impact of monetary policy moves on asset prices, it does not say anything about the statistical significance of the impacts. Also, the changes in asset prices as appearing in Table 5 and 6 may have been responses to shocks other than monetary policy. In order to address these problems, I provide the results of a simple regression analysis of daily asset price changes in the following.

The specification of the equations estimated is a simple one. The dependent variables are the asset price changes. The independent variables are dummies that correspond to the monetary policy moves as summarized in Table 2 along with other variables that may affect the asset prices. More specifically, all equations include as explanatory variables the monetary policy dummies, the overnight call market rate and 10 year U.S. Treasury yield. ${ }^{25}$ In addition, the equation for TOPIX includes S\&P500 and 10 year, both lagged one period. The equation for the yen/dollar rate includes the dollar/euro rate. All variables except the monetary policy dummies are daily changes. ${ }^{26}$ Thus, the policy dummies are assumed to exert permanent effects on the levels of asset prices. The estimation period is March 18, 1999 through March 28, 2011.

The estimation results are summarized in Table 7 . In the table only the effects of the monetary policy measures are shown. The cells shaded indicate that the monetary

\footnotetext{
${ }^{25}$ Given the time difference between Tokyo and New York or London, foreign variables are lagged by a day.

${ }^{26}$ The equity price indexes and the exchange rates are in logarithmic first differences. In the regression analysis I use TOPIX rather than Nikkei225 because there were some serious discontinuities in the latter at the time of the change in the index.
} 
policy dummy is statistically significant at least at the $90 \%$ level. ${ }^{27}$ Roughly speaking, the statistical significance indicates that the effects of the policy dummies as shown in Table 2 are larger than the standard deviation of the error term of the equations. The regression procedure also purges the movements in the asset prices of the effects coming from those in other asset prices. In this sense it remedies some of the serious deficiencies of the news analysis approach.

As expected, the number of policy measures that exerted statistically significant effects on asset prices is not very large. The general pattern of the effects, however, is not very different from that indicated by Table 5. Thus, the ZIRP introduced in April 1999 generated significant effects on interest rates. The QEJ policy announced in March 2001 moved both the interest rates and TOPIX. Some other QEJ measures that were accompanied by increases in JGB purchases affected TOPIX or the JGB rate. In contrast, pure QE0 type measures had little effects on asset prices with the exception of the effect of the April 2003 increase in the CABs on TOPIX. Very few measures affected the yen/dollar rate. The exception is the easing which involved an outright policy rate cut in late 2008 and the introduction of the fixed rate term fund supplying operations in December 2009 which was coupled with Strategy 1, clarification of price stability. In addition, the term fund supplying operation had significant effects on the interest rates. So did the CME introduced in 2010 and expanded in 2011.

Put differently, the forward guidance strategy and some of the QE1 and QE2 type measures exerted significant effects on interest rates and to some extent on stock prices. The exchange rate was affected only when there were major policy changes such as a policy rate cut and the introduction of a term fund supplying operation at a fixed rate. The effects of equity and ABS purchases were limited. Perhaps, in the case of ABS the small size of the market and hence that of the BOJ operations were a constraint. The failure to find significant effect of equity purchases on equity prices, especially those announced in September 2002 is a puzzle, but could be explained by strong negative pressure on the market generated by the serious bad loan problem prevailing at the time.

In passing, it is interesting to see what happens if we applied the same regression method to the U.S. data. Table 8 shows such regression results. For the U.S. case, weekly data is used because variables representing the state of the economy are available at weekly frequency. Specifically, I use weekly initial claims for

\footnotetext{
${ }^{27}$ For each policy measure a dummy is created for the day of the policy change and the day that followed. If one of the two dummies is significant with the right sign and if the sum of the coefficients on the two dummies is of the right sign, the cell is shaded in the table. For the introduction of the ZIRP only one dummy that takes the value of one for four weeks following the policy announcement and zero otherwise is used. This is based on the results in Table 5 .
} 
unemployment insurance as an independent variable along with two year OIS rates, a measure of the market's expectation of near-term policy rate, and monetary policy dummies. The policy dummies correspond to the four dates indicated in Table 4. The estimation period is November 2008 through March 2011.

As can be seen, the initial announcement of MBS and agency debt purchases and the March 2009 expansion of the QE program in quantity and into U.S. treasury bonds exerted significant effects on Treasury bond yields and either on the stock or foreign exchange market. However, the clarification of the initial program in December 2008 and the announcement of the second round of large Treasury bond purchases are not significant. This is somewhat of a puzzle, especially with respect to the November 2010 measure, given the significant rise in stock prices. However, the rise in stock prices is explained by improvements (=declines) in unemployment claims in the equation. I also tried restricting the fourth dummy to the week of August 10 or November 3, but found similar results.

Consequently, we may conclude that the effects of non-conventional monetary policy measures on asset prices have been broadly similar between Japan and the U.S.

\section{4, Discussion}

\section{Statistical Results and Monetary Policy Measures Adopted Since 2007}

The foregoing statistical analysis provides an interesting background for the discussion of the reasons for the choice of policy measures adopted by G7 central banks since 2007.

As pointed out in section 2, most central banks have relied heavily on strategy (ii) since 2007. On the other hand, strategy (i) or (iii) has not been widely used. Of course, strategy (iii) has been employed in weak forms by most major central banks. As discussed above, however, this was mostly a result of strategy (ii) and the decision by central banks not to drain the financial system of excess reserves supplied. Very few central banks, with the exception of the BOE, have stated that the expansion of central bank balance sheets or some measure of the quantity of money by itself exerts strong positive effects on the economy.

Such characteristics of the monetary policy measures adopted during the current episode seem to be the result of two factors: one, the major problem central banks faced was the financial crisis rather than serious deflation; and, the other, central banks seem to have learned about the pros and cons of non-traditional policies from the BOJ's experience. 
As shown in Figure 1, the core CPI inflation rates in the U.S. and EU are surprisingly high despite the severity of the recession in 2008 and 2009. As stated by Taylor (2009), inflation and output alone do not seem to justify near zero levels of the policy rate. Thus, even the setting of the level of the policy rate, the conventional policy tool, has been significantly influenced by financial system considerations. Needless to say, the heavy use of strategy (ii) type measures is explained by the same factor.

The unpopularity of strategy (i) or (iii) may have been partially a result of the BOJ experience during 1999-2006. As analyzed in the previous section, there is not much evidence in favor of the effectiveness of strategy (iii), or QE0. This may have affected the choice of strategy by other central banks.

Strategy (i) has been found to be effective. This strategy, however, has its own limitations. First, it requires forces other than monetary policy to lift the economy out of a liquidity trap. This is because the essence of the strategy is affecting expectations of the level of the policy rate when a zero or very low rate is no longer necessary. If the probability of the economy getting out of the liquidity trap is zero, this strategy is not going to work. This means that, depending on what will happen to exogenous shocks, or in other words, to the natural rate of interest, the economy under strategy (i) could be stuck at a zero interest rate for an embarrassingly long period of time. ${ }^{28}$ The BOJ essentially was unable to, except for a brief interruption in 2000-2001, exit from the ZIRP for more than 6 years.

The second serious problem with the expectations management approach is that it may not be time consistent. It is a promise of monetary expansion when the economy is out of the liquidity trap that generates easing effects. A central bank that finds that the economy is out of the trap, however, may not want to carry out the promised monetary expansion. In other words, a central bank that uses the approach needs to commit to a higher inflation target than usual, or accept the risk of inflation temporarily overshooting the target. In either case, the central bank has an incentive to renege on its promise. As King (2004) puts it, whether or not collective decision making today can bind that of future decision makers is a difficult question.

The above discussion suggests an alternative explanation for the unpopularity of strategy (i) in the current episode. Central banks currently may not want to raise their inflation targets or accept periods of higher inflation than existing target as would be the case if they were seriously following strategy (i). This is because the actual rate of

\footnotetext{
${ }^{28}$ See, however, Eggertson \& Krugman (2011) for an attempt to construct a model in which the decline in the natural rate is motivated by deleveraging attempts by borrowers. Extensions of such a model may allow one to determine the length of the period of low natural rate as a function of other macroeconomic variables including policy.
} 
inflation is still clearly positive in the U.S. or EU as we saw in Figure 1. Also, the build-up of budget deficits and government debt pose obvious risks for large increases in future rates of inflation. Such a line of thinking is somewhat understandable, but deprives central banks of an important policy tool at the ZLB.

\section{Japan's Failure to Stop Deflation}

The evidence on the effects of non-conventional measures as provided in section 3 shows that some of the policy measures adopted by the BOJ did generate expected effects on asset prices. Despite this, Japan has suffered from near zero or negative rates of inflation for more than a decade. The real growth rate of the economy between 1999 and 2010, the period of the current study, averaged at an anemic $0.825 \%$. Clearly, the policy measures have not been powerful enough to lift the economy. In the following I discuss some possible reasons for such disappointing effects of non-conventional monetary policy measures.

First and foremost, negative shocks to the economy have been unprecedented. They began with the burst of Japan's bubble in land and stock prices and their effects on the financial system. Serious negative interactions between asset prices, the health of the financial system and the economy continued well into the mid-2000s. The deflationary forces generated by these shocks forced the BOJ to lower short-term rates to zero first and then to adopt non-conventional monetary policy measures, but they also constrained the effectiveness of the easing policy measures. The burst of the so-called IT bubble then was a headwind for QEJ adopted in the early to mid-2000s. A brief period of a non-zero policy rate, 2006-2008, came to an end as a result of the world financial and economic crisis that began in 2007. The seriousness of the crisis is evident from the failure of other advanced economies to clearly recover from the recession of 2008-09 even at the time of writing. The Japanese economy has been further hit by the earthquake to her northeastern region in 2011.

It is important to point out that some of such negative shocks to the economy were partly a result of inadequate policy making, including monetary policy. It goes without saying that the formation of the land and equity price bubble in the late 1980s was largely a result of an ultra-easy monetary policy environment. In addition, policies to address the deterioration of the balance sheets of financial institutions did not come very quickly. As a result, the negative spiral between declining asset prices and the bad loan problem became very serious.

I may also add a possibility that the pace of the interest rate cut in the early to 
mid- 1990s may not have been fast enough. In fact, the BOJ' official economic outlook had not taken note of the negative effects of the balance sheet problems of financial institutions and borrowers on the economy until $1994 .{ }^{29}$ In other words, in the early to mid- 1990s the BOJ was proceeding on the assumption that the economy was undergoing a usual recession.

Turning more directly to the transmission mechanism of non-conventional policy, I would like to point out that many elements of the measures adopted worked in the direction of lowering interest rate spreads and/or risk premiums. In fact, the typology offered in section 2 can be used to appreciate this point. Strategy (i), forward guidance, by construction is an attempt to reduce long-short interest rate spreads up to a certain maturity, although it may widen the spreads beyond that maturity if it succeeds in raising inflationary expectations. Turning to Strategy (ii), QE1 is, by definition, an attempt to reduce risk/liquidity premiums in markets that are temporarily dysfunctional. QE2 lowers the risk premium of the asset bought by the central bank and also leads to reductions in risk premiums on other assets if it leads to portfolio rebalancing by investors.

Figure 2 shows the spreads between swap rates and the overnight rate for selected maturities in Japan and the U.S. It may be seen that the spreads have steadily narrowed in Japan as more and more non-conventional monetary policy measures have been used since the mid 1990s. The spreads are, however, still very wide in the U.S. despite the adoption of some non-conventional measures. Moreover, the spreads have moved up and down over time in the U.S., while they have not exhibited such movements in Japan. The general pattern is quite similar if corporate bond yields are used in place of the swap rates.

The dynamic movements in the spreads in the U.S. are a result of movements in the monetary policy rate. This is seen from Figure 3 which shows the spreads along with the federal funds rate. A reduction in the federal funds rate (=an upward movement in the chart) leads to corresponding declines in short rates, but to a smaller decline in the long rate, thus widening the spread. In contrast, such fluctuations in the spreads emanating from the cycle of monetary easing and tightening are no longer observable in the Japanese data. ${ }^{30}$

In principle, lower long-short spreads and risk premiums will stimulate aggregate demand. At the same time, however, such interest rate spreads are normally the basis on

\footnotetext{
${ }^{29}$ See, for example, Ueda (2010).

30 This suggests another problem with keeping a zero rate for an extended period. It deprives potential borrowers of funds the incentive to look for the best timing to borrow funds and thus lowers the response of borrowing to interest rates.
} 
which financial intermediaries earn profits. Thus, monetary easing stimulates both the demand and supply side of the credit market, by lowering the rate borrowers face on the one hand, but also by increasing the spread received by intermediaries. The central bank is certainly encouraged to contain abnormal temporary increases in liquidity/risk premiums by operations in dysfunctional markets, that is, by adopting QE1 type measures. However, the central bank needs to carry on operations for an extended period to hold down spreads in more normal markets as is the case with some QE2 type measures. In such a case, intermediation by private financial institutions will be hampered, while the central bank plays the role of an intermediary. As the share of intermediation by the central bank rises, the efficiency of intermediation will naturally decline.

Consequently, an extensive use of non-conventional monetary policy measures, unless it succeeds in turning the economy around within a reasonably short period of time, may run the risk of undermining the economy's ability to find profitable investment opportunities. Needless to say, had the ZIRP or QEJ succeeded in raising inflation expectations on a significant scale for a sustained period, interest rate spreads would have increased. The entrenched nature of deflationary expectations, however, seems to have prevented this. Unfortunately, the Japanese economy seems to be trapped in an "equilibrium" whereby only exogenous forces generate movements to a better equilibrium with a higher rate of inflation. ${ }^{31}$

\section{References}

Allen, F. \& D. Gale (2008) Understanding Financial Crises, Clarendon Lectures in Finance, Oxford University Press.

Baba, N, M. Nakashima, Y. Shigemi \& K. Ueda (2006) “The Bank of Japan's Monetary Policy and Bank Risk Premiums in the Money Market," International Journal of Central Banking, Vol. 2, No.1, March, pp.105-136.

Bank of Japan (2009) Financial Markets Report, Financial Markets Department, August 31.

Bernanke, B.S. (2009) "Reflections on a Year of Crisis," speech at the Federal Reserve Bank of Kansas City's Annual Economic Symposium, Jackson Hole, Wyoming. \& V. R. Reinhart (2004), "Conducting Monetary Policy at Very Low Short-Term Interest Rates," American Economic Review, Vol. 94, No. 2,

31 One experiment that has not been tried is a large scale fiscal expenditure financed by purchases of government bonds by the BOJ. This, however, surely runs the risk of creating run-away inflation. 
pp.85-90.

$\longrightarrow,-, \&$ B. P. Sack (2004), "Monetary Policy Alternatives at the Zero Bound: An Empirical Assessment," Brookings Papers on Economic Activity, 2:2004, pp. $1-78$.

Clarida, R. (2010) "What Has--and Has Not--Been Learned about Monetary Policy in a Low Inflation Environment? A Review of the 2000s," paper presented at the Federal Reserve Bank of Boston 55th Economic Conference, October 14-16.

D’Amico S. \& T. B. King (2010) "Flow and Stock Effects of Large-Scale Treasury Purchases," Finance and Economics Discussion Series 2010-52, Division of Research \& Statistics and Monetary Affairs, Federal Reserve Board.

Doh, T. (2010) "The Efficacy of Large-Scale Asset Purchases at the Zero Lower Bound," Economic Review, Federal Reserve Bank of Kansas City, $2^{\text {nd }}$ Quarter, pp. 5-34.

Curdia, V. \& M. Woodford (2010) "The Central-Bank Balance Sheet as an Instrument of Monetary Policy," paper presented at the 75th Carnegie-Rochester Conference on Public Policy, April 16-17.

Eggertsson, G. B. and P. Krugman (2011) "Debt, Deleveraging, and the Liquidity Trap: A Fisher-Minsky-Koo Approach," paper presented at the NBER Japan Project Meeting, June 24-25, 2011, Tokyo.

Gagnon, J. M. Raskin, J. Remache and B. Sack (2010) "Large Scale Asset Purchases by the Federal Reserve: Did They Work?" Staff Report No.441, Federal Reserve Bank of New York.

King, M. (2004) “The Institutions of Monetary Policy,” American Economic Review, Vol.94, May, pp. 1-13.

Krishnamurthy, A. \& A. Vissing-Jorgensen (2011) "The Effects of Quantitative Easing On Interest Rates," mimeo., Northwestern University.

Krugman, P. (1998) "It’s Baaack! Japan’s Slump and the Return of the Liquidity Trap," Brookings Papers on Economic Activity, 2, pp. 137-187.

Lam, W. Raphael (2011) “Bank of Japan’s Monetary Easing Measures: Are They Powerful and Comprehensive?" IMF Working Paper.

Madigan, B. F. (2009) “Bagehot's Dictum in Practice: Formulating and Implementing 
Policies to Combat the Financial Crises," speech at the Federal Reserve Bank of Kansas City's Annual Economic Symposium, Jackson Hole, Wyoming.

McCauley, R. N. \& K. Ueda (2009) “Government Debt Management at Low Interest Rates," BIS Quarterly Review, June.

Modigliani, F. \& R. Sutch (1966) "Innovations in Interest Rate Policy,” American Economic Review, Vol.56, No.1/2, pp.178-197.

Oda, N. \& K. Ueda (2007) “The Effects of the Bank of Japan's Zero Interest Rate Commitment and Quantitative Monetary Easing on the Yield Curve: A MacroFinance Approach,” Japanese Economic Review, Vo. 58, No.3, September, pp. 303-328.

Okina, K. \& S. Shiratsuka (2004) "Policy Commitment and Expectation Formation: Japan's Experience under Zero Interest Rates,” North American Journal of Economics and Finance, Vol. 15, No.1, pp. 75-100.

Taylor, John B., 2009, "The financial crisis and policy responses: An empirical analysis of what went wrong," NBER Working Paper No. 14631.

Ueda, K. (2005) “The Bank of Japan's Struggle with the Lower Bound on Nominal Interest Rates: Exercises in Expectations Management," International Finance, Vo.8, No.2, Summer, pp.329-350. (2010) "Regulation, Supervisory Lessons from Japan since the 1990s," Journal of Regulation \& Risk: North Asia, Vol.2, No.1, pp.87-98.

Ugai, H. (2007) "Effects of the Quantitative Easing Policy: A Survey of Empirical Analysis," Monetary and Economic Studies, Vo.25, No.1, Bank of Japan, pp. $1-47$.

Woodford, Michael (1999), "Commentary: How Should Monetary Policy Be Conducted in an Era of Price Stability?" Remarks at a symposium sponsored by the Federal Reserve Bank of Kansas City, Jackson Hole, Wyoming.

Yellen, J. L. (2011) "Unconventional Monetary Policy and Central Bank Communication," Remarks at the U.S. Monetary Policy Forum, N.Y., N.Y. 
Table 1 Policy Options near the ZLB

\begin{tabular}{|l|l|l|}
\hline Strategy i & managing expectations about future levels of the policy rate & \\
\hline intended effect & today's medium- and long-term rates will be affected & \\
\hline & & without \\
\hline Strategy ii & $\begin{array}{l}\text { targeted asset purchases } \\
\text { (may include lending against non-traditional assets) }\end{array}$ & sterilization \\
\hline intended effect & portfolio rebalancing & QE2 \\
\hline & liquidity premiums in dysfunctional markets will be reduced & QE1 \\
\hline & \multicolumn{1}{|l}{} & \\
\hline Strategy ii & Quantitative Easing (purchase TBs to raise excess reserves) & \\
\hline intended effect & inflation expectations may rise? & QE0 \\
\hline
\end{tabular}

Table 2 Chronology of Policy Measures Adopted by the BOJ

\begin{tabular}{|c|c|c|c|c|c|c|}
\hline & & Strategy & Strategy 2 & & Strategy & Policy rate \\
\hline & & & QE1 & QE2 & QEO & \\
\hline ZIRP & 1999.4 .13 & $*$ & & & & \\
\hline QEJ announced & 2001.3.19 & * & & * (JGB) & $*$ & \\
\hline QEJ expanded & 2001.8 .14 & & & * (JGB) & * & \\
\hline QEJ expanded & 2001.12 .19 & & & * (JGB) & $*$ & \\
\hline JGB purchase increased & 2002.2 .28 & & & * (JGB) & & \\
\hline Stock purchase announced & 2002.9 .18 & & *(equities) & & & \\
\hline QEJ expanded & 2002.10 .30 & & & $*$ (JGB) & $*$ & \\
\hline Stock purchase expanded & 2003.3 .25 & & *(equities) & & & \\
\hline ABS purchase announced & 2003.4 .8 & & $*(\mathrm{ABS})$ & & & \\
\hline QEJ expanded & 2003.4 .30 & & & & $*$ & \\
\hline QEJ expanded & 2003.5 .20 & & & & $*$ & \\
\hline QEJ expanded & 2003.10 .10 & $*$ & & & $*$ & \\
\hline QEJ expanded & 2004.1 .20 & & & & $*$ & \\
\hline QEJ terminated & 2006.3.9 & & & & & \\
\hline Dollar Swap & 2008.9.18 & & *(US Dolla & & & \\
\hline Facilitation of Corporate Finance & 2008.12 .2 & & $* 1$ & & & \\
\hline JGB purchase increased & 2008.12 .19 & & *(CP,JGBI & $*(J G B)$ & & $*$ \\
\hline stock purchase restarted & 2009.2 .3 & & *(equities) & & & \\
\hline JGB purchase increased & 2009.3.18 & & & *(JGB) & & \\
\hline Fixed rate $3 \mathrm{M}$ operation & 2009.12 .1 & & $*$ & & & \\
\hline "Inflation target" clarified & 2009.12 .18 & * & & & & \\
\hline Fixed Rate Ope. Expanded & 2010.3.17 & & $*$ & & & \\
\hline Growth enhancing ope. & 2010.5 .17 & & $* 2$ & & & \\
\hline Fixed rate $6 \mathrm{M}$ operation & 2010.8 .30 & & $*$ & & & \\
\hline CMP introduced & 2010.10 .5 & * & $* 3$ & $* 3$ & & \\
\hline CMP expanded & 2011.3 .14 & & $*$ & $*$ & & \\
\hline
\end{tabular}

*1 collateral requirement against $\mathrm{BOJ}$ lending relaxed

$* 2$ back financing at fixed term rate of growth enhancing lending

*3 Fixed rate fund supplying operartion expanded. A new framework, comprehenisive monetary policy (CMP), to

purchases JGBs, CPs, corporate bonds, ETFs, and J-REITs announced. 
Table 3 Examples of Non-traditional Policies during 2007-2009

\begin{tabular}{|l|l|}
\hline Strategy i & $\begin{array}{l}\text { "The O/N rate can be expected to remain at current level until 2010QII } \\
\text { (Bank of Canada, April 2009), "the committee anticipates economic conditions } \\
\text { are likely to warrant low levels of the federal funds rate." (Fed) }\end{array}$ \\
\hline Strategy ii & $\begin{array}{l}\text { purchases of corporate bonds ( BOE), covered bonds (ECB), } \\
\text { Agency bonds, Agency MBS (Fed) } \\
\text { lending against securitized assets (Fed) } \\
\text { fixed rate full allotment liquidity provision at below market rates (ECB) } \\
\text { US dollar repo (major central banks) }\end{array}$ \\
\hline & \multicolumn{1}{|c|}{} \\
\hline Strategy ii & BOE's Asset Purchase Facility \\
\hline
\end{tabular}

\section{Table 4}

$$
\begin{aligned}
& \text { Responses of Longer-Term Interest Rates } \\
& \text { to News about the FED's Asset Purchases }
\end{aligned}
$$

\begin{tabular}{|l|c|c|c|c|}
\hline Date & 10 yr Treasury & 10 yr TIPS & 30 yr MBS & $\begin{array}{c}10 \text { yr BBB } \\
\text { corporate bonds }\end{array}$ \\
\hline Nov. 25, 2008 & -21 & -24 & -44 & -16 \\
\hline Dec.1, 2008 & -20 & -22 & -12 & -25 \\
\hline March 18,2009 & -50 & -49 & -15 & -47 \\
\hline Aug.10-Nov. 3,2010 & -15 & -54 & -13 & -22 \\
\hline
\end{tabular}

Note: Entries are yield changes in basis points on the day of the policy announcement except for the 2010 measure and are taken from Yellen (2011). 


\begin{tabular}{|c|c|c|c|c|c|c|c|c|c|c|}
\hline & \multicolumn{8}{|c|}{ Table 5 Asset Price Responses to the BOJ's Monetary Policy Measures } & \multirow{2}{*}{\multicolumn{2}{|c|}{ Corporate Bonds }} \\
\hline & & \multirow[b]{2}{*}{ window } & \multicolumn{3}{|c|}{ jJGB yields } & \multirow[b]{2}{*}{$10 \mathrm{Yr}$} & \multirow[b]{2}{*}{$30 \mathrm{Yr}$} & ¡SWAP & & \\
\hline & & & ¡TOPIX & ¡2Yr & $5 \mathrm{Yr}$ & & & i1 $1 \mathrm{Yr}$ & iA & ¡dollar/yer \\
\hline \multirow[t]{3}{*}{ ZIRP } & 1999.4 & 2D & 1.6 & 1 & 4.6 & 7.5 & & 0.5 & 4.9 & -1.35 \\
\hline & & $1 \mathrm{~W}$ & 1 & -3.7 & -4.2 & 0.9 & & -3.5 & -2.8 & -2.3 \\
\hline & & $1 \mathrm{M}$ & 2.7. & -13.6 & -20.9 & -22.7 & & -8.5 & -30.7 & 0.475 \\
\hline "Inflation target" clarified & 2009.12 .18 & $2 \mathrm{D}$ & 0.19 & -0.6 & -5.9 & -2.8 & -3.6 & -1.3 & -2.8 & 1.33 \\
\hline \multicolumn{11}{|l|}{ QEJ } \\
\hline those with decisions & 2001.3.19 & 2D & 7.12 & -3.1 & -5.3 & -7.7 & -16.4 & 1 & -1.2 & -0.68 \\
\hline \multirow[t]{5}{*}{ on JGB purchases } & & $1 \mathrm{~W}$ & 13.3 & 1.6 & 4.6 & 0.5 & -3.2 & 3 & 3.1 & -0.37 \\
\hline & 2001.8.14 & 2D & 2.42 & -3.6 & -4.3 & -0.5 & 0 & -1.6 & -3.8 & -2.38 \\
\hline & 2001.12 .19 & 2D & 0.02 & -0.4 & -1.2 & -0.4 & -0.8 & -2 & 0.9 & 0.63 \\
\hline & 2002.2.28 & 2D & 2.26 & -3.7 & -2 & -2.3 & -3.1 & -3 & 2.5 & -0.61 \\
\hline & 2002.10 .30 & 2D & -0.78 & -0.4 & -0.2 & -4.8 & -7.9 & -0.8 & -1.6 & -0.48 \\
\hline \multicolumn{11}{|l|}{$\overline{\mathrm{QEJ}}$} \\
\hline \multirow[t]{4}{*}{ QEO } & 2003.4 .30 & 2D & 3.36 & -0.6 & -1 & 0.1 & 0 & -0.1 & -2.9 & -0.98 \\
\hline & 2003.5 .20 & 2D & -0.25 & 0.1 & -1.4 & -2.9 & -2.6 & -0.3 & 0.3 & 0.39 \\
\hline & 2003.10.10 & 2D & 4.13 & -0.4 & 2.1 & 5.2 & 4.5 & 1 & 0.1 & -0.14 \\
\hline & 2004.1 .20 & $2 \mathrm{D}$ & -0.31 & $=0.8$ & 1.4 & 4.8 & $-\underline{5}$ & 0.9 & 4.5 & $=0.33$ \\
\hline QEJ exit & 2006.3 .9 & 2D & 3.12 & -0.6 & 2.4 & 4.7 & 6 & 1.5 & 0.4 & 0.98 \\
\hline Dollar Swap & 2008.9 .18 & 2D & 1.46 & 5.6 & 4.8 & -0.8 & 2.2 & 2.4 & 8.2 & 2.67 \\
\hline Facilitation of Corporate Finance & 2008.12 .2 & 2D & -4.68 & -3.6 & 0 & -2.2 & -1.6 & 0.4 & 9.1 & 0.12 \\
\hline JGB purchase increased & 2008.12.19 & 2D & 0.65 & -5.2 & -4.5 & -4.6 & -13.7 & -5.8 & -1.6 & 0.81 \\
\hline JGB purchase increased & 2009.3.18 & 2D & -0.04 & -1.3 & -5.8 & -4 & 1 & -2.5 & -3.4 & -4.13 \\
\hline Fixed rate $3 \mathrm{M}$ operation & 2009.12 .1 & 2D & 2.82 & -5.1 & -6 & -1.5 & -5.1 & -4.5 & -6.5 & 1.13 \\
\hline Fixed Rate Ope. Expanded & 2010.3.17 & 2D & 0.21 & 0 & 2.3 & 2.3 & 0 & 0.1 & 2.6 & 0.89 \\
\hline Growth enhancing ope. & 2010.5.17 & 2D & -2.1 & 0.4 & 0.1 & 0 & 1.3 & 0.4 & -0.6 & -0.26 \\
\hline Fixed rate $6 \mathrm{M}$ operation & 2010.8 .30 & 2D & -1.86 & -0.9 & -2.8 & -3.6 & -3.1 & -0.9 & -3.2 & -1.21 \\
\hline CMP introduced & 2010.10 .5 & 2D & 3.3 & -1.5 & -4.4 & -9.9 & -0.9 & -1.7 & -5.4 & -0.52 \\
\hline \multirow[t]{4}{*}{ CMP expanded } & 2011.3 & 2D & -16.1 & 0.2 & -5.1 & -3.2 & 6.2 & -0.9 & -6 & -1.12 \\
\hline & & & \multirow{2}{*}{\multicolumn{7}{|c|}{$\begin{array}{l}\text { *Entries are rates of change over two days for TOPIX and the dollar/yen ate } \\
\text { and changes in yields for others over two days unless otherwise indicated. }\end{array}$}} & \\
\hline & & & & & & & & & & \\
\hline & & & \multicolumn{7}{|c|}{ ** Positive entries for dollar/yen mean yen depreciation. } & \\
\hline
\end{tabular}

Table 6 Asset Price Responses to Targeted Asset Purchases

\begin{tabular}{|c|c|c|c|c|c|c|}
\hline & & I TOPIX & $110 Y \mathrm{YJC}$ & I1Yr SWAP I & Corporate bonds I & I dollar/yen \\
\hline equity purchases from banks & 2002.9 .18 & 1.32 & 12 & $-0.4 i$ & 9.9 & -0.59 \\
\hline equity purchases expanded & 2003.3 .25 & -2.43 & -2.9 & 0 & -1.4 & -0.7 \\
\hline equity purchases resumed & 2009.2 .3 & 2.1 & 5.3 & -1.1 & 13.8 & 0 \\
\hline ABS purchases & 2003.4.8 & i -2.33 & -3.7 & $-5 i$ & 0.31 & 0.3 \\
\hline
\end{tabular}

\begin{tabular}{|l|r|r|||}
\hline & \multicolumn{2}{|c|}{ inflation indexed bonds } \\
\hline JGB purchases increased & 2008.12 .19 & -0.521 \\
\hline the same as above & 2009.3 .18 & -0.221 \\
\hline CMP & 2010.10 .5 & -0.34 \\
\hline CMP expanded & 2011.3 .14 & -0.07 \\
\hline
\end{tabular}

TOPIX and the dollar/yen rate are rate of changes. Others are yield changes.

Inflation indexed bonds are of 7 year maturity after Dec. 2009 and ten year, before. 
Table 7 Regression Results on the Effectiveness of Policy Measures

\begin{tabular}{|c|c|c|c|c|c|}
\hline & & & JGB & SWAP & \\
\hline & & TOPIX & $10 \mathrm{yr}$ & $1 \mathrm{yr}$ & Yen/dollar \\
\hline$\overline{Z I R P}$ & 1999.4 .13 & & & & \\
\hline Clarifying price stability & 2009.12 .18 & & & & \\
\hline QEJ & 2001.3.19 & & & & \\
\hline with increases in JGB & 2001.8.14 & & & & \\
\hline \multirow[t]{3}{*}{ purchases } & 2001.12.19 & & & & \\
\hline & 2002.2 .28 & & & & \\
\hline & 2002.10 .30 & & & & \\
\hline$\overline{\text { QEJ }}$ & 2003.4 .30 & & & & \\
\hline \multirow[t]{3}{*}{ QE0 } & 2003.5.20 & & & & \\
\hline & 2003.10.10 & & & & \\
\hline & 2004.1.20 & & & & \\
\hline Facilitation of Corporate Finance & 2008.12 .2 & & & & \\
\hline JGB purchase increased & 2008.12.19 & & & & \\
\hline JGB purchase increased & 2009.3.18 & & & & \\
\hline Fixed rate $3 \mathrm{M}$ operation & 2009.12 .1 & & & & \\
\hline Fixed Rate Ope. Expanded & 2010.3.17 & & & & \\
\hline Growth enhancing ope. & 2010.5.17 & & & & \\
\hline Fixed rate $6 \mathrm{M}$ operation & 2010.8.30 & & & & \\
\hline CMP introduced & 2010.10 .5 & & & & \\
\hline CMP expanded & 2011.3 .14 & & & & \\
\hline equity purchases from banks & 2002.9 .18 & & & & \\
\hline equity purchases expanded & 2003.3.25 & & & & \\
\hline equity purchases resumed & 2009.2 .3 & & & & \\
\hline ABS purchases & 2003.4.8 & & & & \\
\hline
\end{tabular}

Table 8 Regression Results on the Effectiveness of the Fed's Monetary Policy Measures

\begin{tabular}{|l|l|l|}
\hline Date & $\begin{array}{l}10 \mathrm{yr} \\
\text { Treasury }\end{array}$ & S\&P500 dollar/Euro \\
\hline Nov. 25, 2008 & & \\
\hline Dec.1, 2008 & & \\
\hline March 18,2009 & & \\
\hline Aug.10-Nov. 3,2010 & & \\
\hline
\end{tabular}




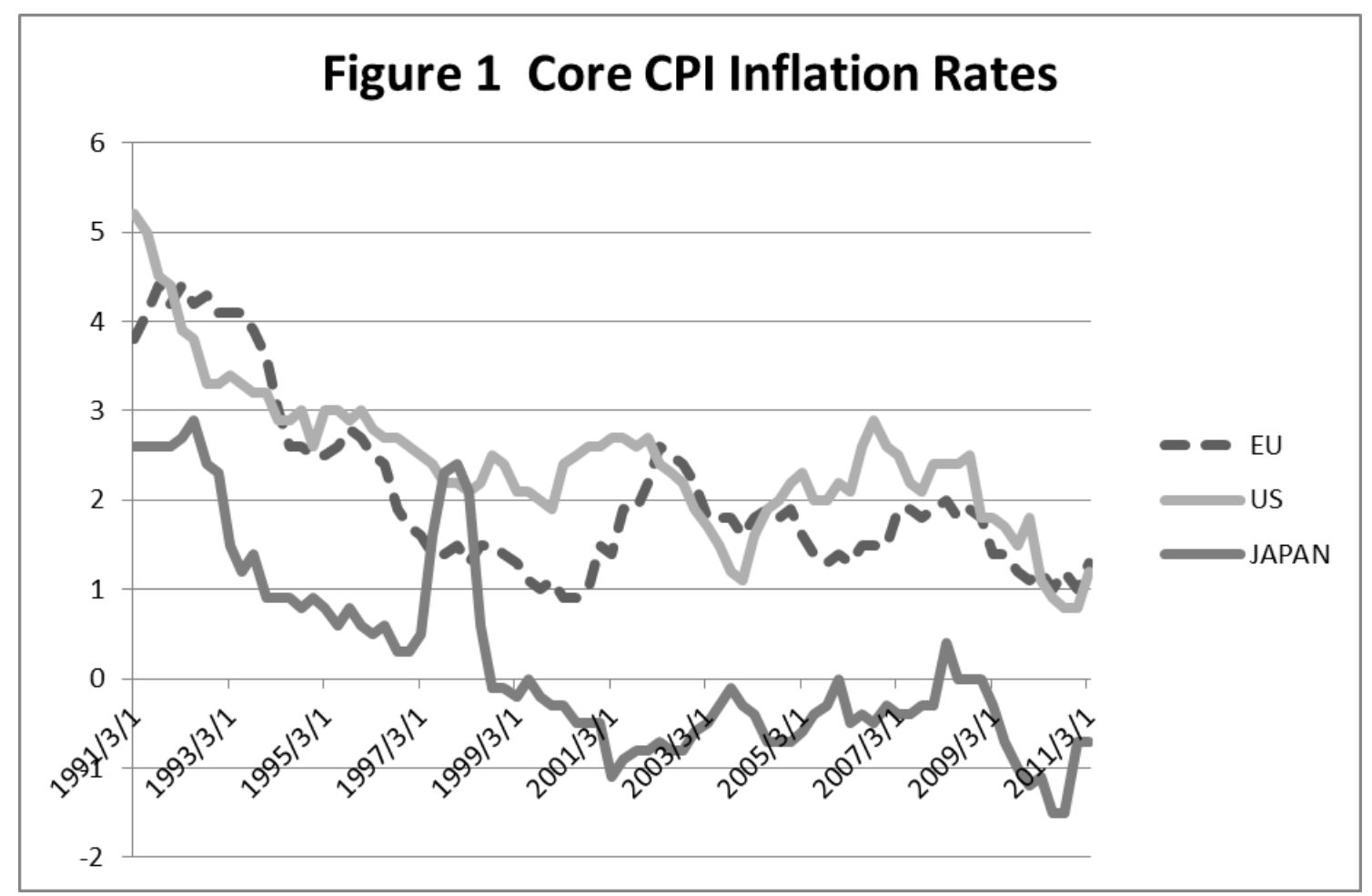

Figure 2 Swap-ON rate spread, US and Japan

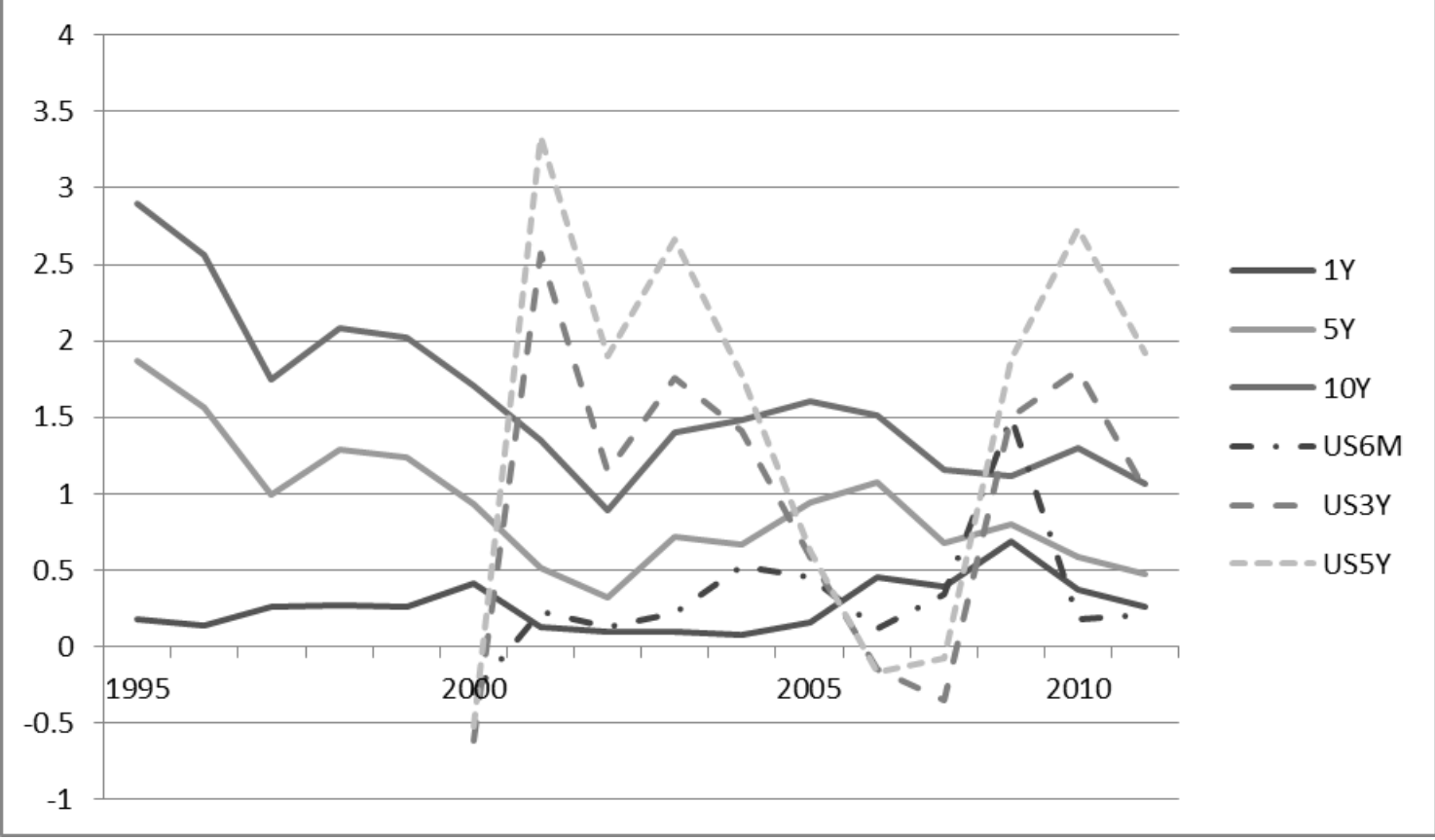




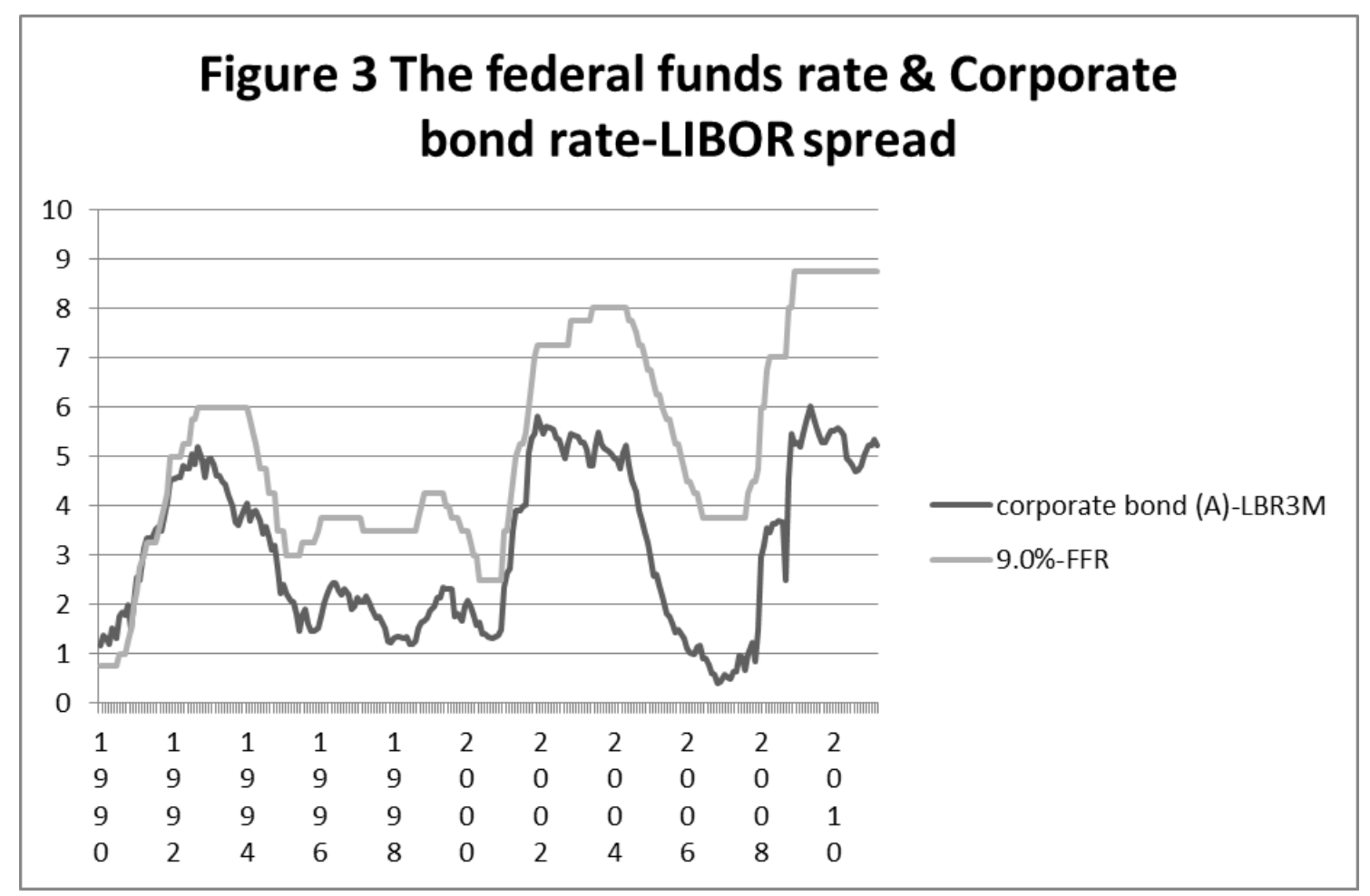

